\title{
Factors Influencing the Attitude of University Students' toward Online Shopping: Evidence from Some Selected Universities of Chittagong
}

\author{
Mir Md. Tariqul Alam ${ }^{1}$ \\ ${ }^{1}$ Department of Marketing, Premier University, Chittagong, Bangladesh \\ Correspondence: Mir Md. Tariqul Islam, Assistant Professor, Department of Marketing, Premier University, \\ Chittagong, Bangladesh. E-mail: tariqultvi@gmail.com
}

Received: September 20, 2018

Accepted: November 6, 2018

Online Published: November 14, 2018

doi:10.5539/ijbm.v13n12p158

URL: https://doi.org/10.5539/ijbm.v13n12p158

\begin{abstract}
Online shopping is gradually becoming more popular across the globe. The current surge in the use of Facebook and other social networking sites has made it draw more attention from the young generation specifically from the students of tertiary level. This study therefore endeavors to identify the factors influencing the attitude of University students' toward online buying of a number of Universities located in Chittagong, Bangladesh. We attempt to find out whether gender, grade, subject major, perceived safety, website construction, and price and quality of products are potential factors of online buying decision. Data are collected through a structured questionnaire. Pearson correlation and regression technique are used for analyzing the data. The empirical results show that major, perceived safety, website construction, price and quality of products have significant impact on the University students' attitude towards online purchasing behavior.
\end{abstract}

Keywords: factors, online shopping, attitude, university students, buying behavior

\section{Introduction}

Online shopping is gradually becoming more popular across the globe. Bangladesh is no exception. The recent surge in the use of Facebook and social networking sites has made it get more attention from the young generation specifically the University students. As a part of e-commerce, online shopping involves the process of searching and getting the information of products and subsequently buying the desired products. This virtual mechanism affects not only the purchasing behavior of customers but also theirs taste and preferences. There are a number of free classified websites and online shopping marketplaces in Bangladesh, including Othoba.com, Bikroy.com, Lamudi, Carmudi, Kaymuand Bagdoom.com etc. According to ProthomAlo in 2014, about 1.5 to 2 million people shopped online every year, and the market is growing by $15 \%$ to $20 \%$. Since the market in online is still on development stage and due to more positive feedback from current customers, the current online marketers are expecting that it will become more competitive in near future. Hence, to meet up the needs and preferences of future customers, the marketers are reshaping their product features and at the same time giving more emphasis on uncovering the factors and motives influencing the online purchasing behavior of the potential customers.

The main objective of this study is to discover the factors driving the online purchasing behavior of the customers. Since University students usually get more attachment of using internet and are relatively good at using latest technologies like smart phones and computers, they can easily engage in online shopping. Moreover, university students are more curious and eagerly wait to accept something new. Therefore, this study has given concentration on a sample of University students to explore the determinants affecting the online buying behavior.

Apart from identification of the factors influencing the buying behavior of University students, the study will give some recommendations so that online marketers can meet up customers' requirements by reshaping the products though incorporation of new features as and when necessary. Moreover, the online marketers can redesign their promotional strategies to attract more customers in future. It is mentionable that discovering the factors affecting the buying behavior is actually receiving the customers' feedback. Hence, the findings of this study will help the online marketers comprehend the demand of the online customers to successfully address the customers' feedback. The study is based on some primary data collected from the students of a few private Universities in Bangladesh namely- Premier University, Chittagong Independent University, East Delta 
University, and International Islamic University Chittagong. All data have been collected by a structured questionnaire.

\section{Literature Review}

Buying behavior has been dealt by a number of studies. The past studies have uncovered many factors that eventually drive customers' behavior in online. However, few studies could be found considering all potential factors affecting the online purchase behavior in a single model. The outcomes of previous studies are presented as below:

Koufaris (2002) assessed factors which have been derived from marketing, information systems, and psychology in a single framework. Pavlou (2003) investigated the interconnection among consumer acceptance of e-commerce and trust, risk, perceived usefulness, and perceived ease of use.

Pavlou and Fygenson (2006) have examined consumer's adoption of e-commerce with the extended theory of planned behavior (TPB) (Ajzen, 1991). They have separately examined consumer behavior in terms of getting information behavior and purchasing behavior influenced by trust and perceived risk, consumer's attitude, social influence, personal online skills, and technology-oriented factors including perceived usefulness, perceived ease of use, and web site features.

Moreover, demographics, channel knowledge, perceived channel utility and shopping orientations are responsible for online purchasing behavior (Li, Cheng, \& Russell, 1999; Weiss, 2001). Several studies have confirmed that consumers are usually older (Bellman et al., 1999; Donthu and Garcia, 1999; Weiss, 2001), educated (Bellman et al., 1999; Li et al., 1999; Swinwyard \& Smith, 2003), had better earnings (Bellman et al., 1999; Li et al., 1999; Donthu \& Garcia, 1999; Swinwyard \& Smith, 2003), and highly captivated to technology (Li et al., 1999; Swinwyard \& Smith, 2003). Men frequently buy products and/or services from the Internet than women (Garbarino \& Strahilevitz, 2004; Korgaonkar \& Wolin, 1999; Slyke et al., 2002). Ensuring time efficiency, avoiding crowds, and ensuring day long purchasingare dedicated to the reasons for online buying (Karayanni, 2003).

Delafrooz et al. (2009) examined the significance of attitude toward online shopping. Data was collected using a five-level Likert scale to determine students' attitudes towards online shopping. They developed a self-administered questionnaire and 370 post-graduate students were selected by random sampling. The regression analysis showed that utilitarian orientation, convenience, price, and wider selection influenced consumers' attitudes towards online shopping.

Jun and Jaafar (2011) used perceived usability, perceived security, perceived privacy, perceived after-sales service, perceived marketing mix, and perceived reputation for analysis. This research located that there have been relationships among the perceived usability, perceived security, perceived privacy, perceived after-sales service, perceived marketing mix, perceived reputation and consumers' attitude to adopting online shopping in China. Nevertheless, only marketing mix and reputation had been determined to seriously have an impact on customers' mindset to undertake on line purchasing.

$\mathrm{Ma}$ and $\mathrm{Ma}$ (2012) assumed that the factors of gender, grade, and major, perceived safety, website construction, price and quality of products have the influence on the attitude of university students towards online shopping. Variation analysis, Pearson correlation coefficient analysis, independent sample t-test were used to analyze the hypotheses. Finally, the result of the analysis showed that the factors of major, perceived safety, website construction, prices and quality of products have the significant influence on university students' attitude toward online shopping.

Sharma and Sitlani (2013) drawn a sample of 200 higher-education students from Indore and have attempted to explore the various factors that may influence the decision to shop online. The results of the study revealed that Internet Traits, Attitudinal Traits, and Convenience significantly affect online shopping behavior of young students, while Perceived Risk in terms of financial risk, privacy, security and product guarantee/warrantee hinders the young students to shop online. Halimi et al. (2012) attempted to find out the factors influencing consumers' attitude toward online shopping among degree holders in Singapore. Their results show that there is a significant relationship between perceived usefulness, perceived ease of use, security and customer's attitude towards online purchasing. Moreover, the relationship between customer's privacy concern and their attitude toward online purchasing is significant but negative. Finally, there is no full-size courting among product traits and consumer's mindset toward on line shopping in Singapore.

AL-Ziadat (2013) attempted to determine the success factors in improving users' attitude towards e-commerce in Jordan with the help of the technology acceptance model (TAM). The studies version accommodates of four 
impartial variables specifically perceived usefulness, perceived ease of use, focus, and trust, and on dependent variable specifically consumers' mind-set towards e-commerce. Questionnaires numbering a hundred are dispensed amongst Mu'tah university graduate college students and the response charge is a great $100 \%$. The findings of the examine show a tremendous and fantastic hyperlink among all 4 variables and mindset closer to e-trade.

Mahmud and Hossain (2014) focused on factors influencing online buyers' attitude based on the evidence from buyers of Dhaka city. It also investigates how distinct varieties of on line buyers perceive web sites in a different way. Data used in this study was obtained using an interviewer-administered structured questionnaire on 199 respondents, selected randomly having experience in online purchasing. Exploratory factor analysis was conducted to factorize seventeen variables along with ANOVA techniques in order to test different hypotheses. Website reliability, website design, website customer service, and website competency are the four dominant factors which influence consumer perceptions of online purchasing. The five types of online buyers, namely, prospective, trial, occasional, frequent and regular online buyers; perceived the four website factors differently except for website design. These buyers have similar evaluations of website design but different evaluations of website reliability and security issues, which imply that security or privacy issues are important to most online buyers.

Makhitha (2014) tried to determine the factors that determine the Generation Y students' attitude towards online shopping in South Africa. The effects of the have a look at indicated that most of the people of technology Y college students do not shop online. However, the generation Y students spend extra time at the net, getting access to the net on an each day foundation. The Generation Y students at different age groups did not differ in attitudes toward online shopping. Generation Y students have been located to be influenced with the aid of the perceived comfort related to on-line buying. Alkasassbeh (2014) aimed to identify factors that affect consumers' attitudes toward online shopping in the city of Tabuk. To reap the goals of the observe, a questionnaire was designed to gather facts and distribute it to have a look at population via polled an easy random pattern of (214) from those who are dealing with the service of online shopping within the metropolis of Tabuk. Results of the study showed the presence of a statistically significant effect of factors (perceived usefulness, perceived ease of use, product involvement, perceived risk) in affecting consumers' attitudes toward online shopping.

Daud (2016) tried to determine the factors that influence students' behavior in online shopping in Malaysia. The study was conducted on 120 students that perusing degree at a public university. It was found that the level of online shopping intention was relatively high and direction of attitude towards online shopping was positive among the postgraduate students. Their results show that utilitarian orientations, hedonic orientation, demographic characteristics, and online shopping perceived benefits and attitudes were the influencing factors of online shopping.

Jadhav and Khanna (2016) explore the factors influencing the online buying behavior of the college students in India. Convenience sampling method was used to choose the sample of 25 college students and qualitative content material analysis became used for analyzing the textual content of the depth interview data. The main influencing factors for online shopping were identified as availability, low price, promotions, comparison, convenience, and customer service, perceived ease of use, attitude, time consciousness, trust, and variety seeking.

Dani (2017) studied consumer's attitudes towards online shopping and specifically studying the factors influencing consumers to shop online. Their findings indicated that among the four factors selected for this research the most attractive and influencing factor for online shoppers in Kanyakumari District is Website Design/Features, following convenience the second most influencing and thirdly time-saving. Results have also shown that security is of important concern among online shoppers in India. The research has also found that there are some other factors which influence online shoppers including, less price, discount, feedback from previous customers and the quality of the product.

Jukariya and Singhvi (2018) examined the key factors which affect buying motives of students of MPUAT, Udaipur for online buying or e-shopping. To investigate this questionnaire method was used. A total of 100 postgraduate students from four colleges of MPUAT, Udaipur, Rajasthan were selected. Students asked their level of agreement on 23 aspects related to online shopping. The study identified that there are Transaction security and multiple payment options, Personal privacy and security, Product price and quality, the speed of access and after - sales service were few major factors that affect students' online shopping behavior.

Rajesh (2018) studied the factors that are influencing for online shopping in the Pune area and to explore the demographic factors, which influence the level of customer satisfaction of online shoppers. Survey method is 
used for data collection through a structured questionnaire based on the demographic profile like gender, age; duration and frequency of online shopping etc. 114 samples were scored on the idea of thirty-four variables of influencers and delight of online customers in Pune location from Maharashtra kingdom in India. The statistical equipment for non-parametric records like Mann Whitney take a look at, Kruskal Wallis take a look at are used for data evaluation. The finding of the study reveals that online customers age does not have an influencing role in preferring factors for online shopping whereas male and female, prefer same parameters for on line shopping in addition to for customer satisfaction and after-sales services.

Perceived safety, website construction, price and quality of products have effect on consumers' attitude towards online shopping found by the past studies. The hardware, software and data in internet system are protected and away from occasional or baleful destroy, modify, and leak confirm safety of online purchasing. Simply, safety in internet means security of information in online environment.

On the other side, in many people's perception they can always get cheaper goods through online shopping, because the companies selling online can save a lot of money compare with traditional seller from such rent fee for the store, agency fee, salaries and so on. However, consumers cannot touch the real products when they make purchase decision via online, which makes part of consumer hesitation about quality of products, and then this doubt affects their buying action. The website construction, the style, sort, compositor, color etc. will directly affect consumers' perception and stay time on the website, thereby affect their purchasing decision.

\section{Theoretical Structure and Development of Hypotheses}

Based on the literature and by following Ma and Ma (2012) the following theoretical model has been established. According to the characteristics of the students from university level, gender, grade and major, perceived safety, website construction, price of products and quality of products are considered as potential factor.

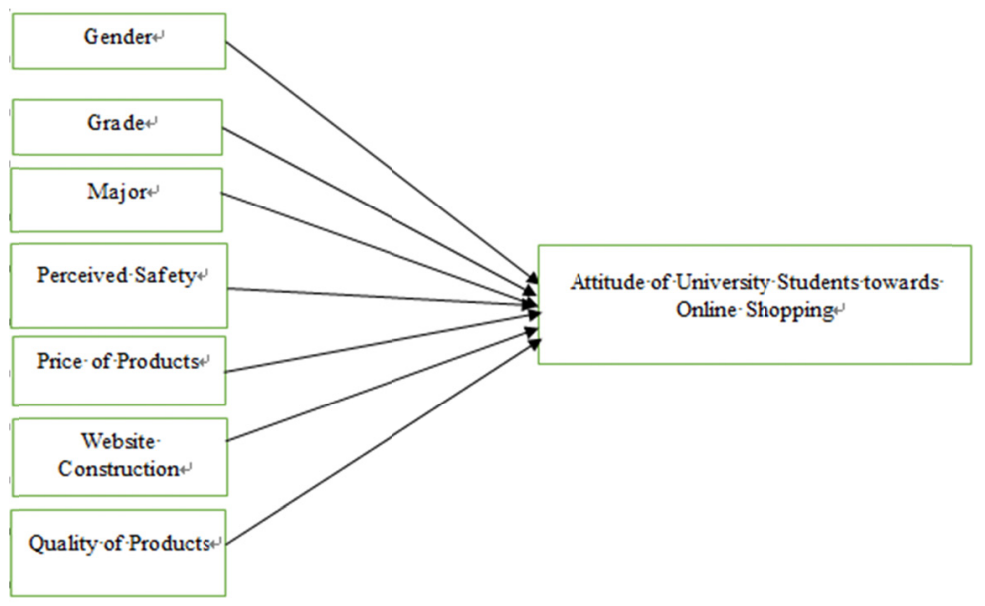

Figure 1. Factors affecting online purchasing behavior

On the basis of conceptual framework, the following hypotheses are developed in order to check the impact of independent variables towards dependent variable. The analysis method along with the hypotheses are presented in the following Table 1.

Table 1. Hypotheses and Analysis Tools used for testing the hypotheses

\begin{tabular}{cll}
\hline Hypotheses & Analysis Method \\
\hline $\mathrm{H}_{1}$ & Attitude towards online buying is not influenced by gender. & Pearson correlation and regression \\
$\mathrm{H}_{2}$ & There is no significant impact of grade on attitude towards online buying. & Pearson correlation and regression \\
$\mathrm{H}_{3}$ & Attitude towards online buying does not differ by major. & Pearson correlation and regression \\
$\mathrm{H}_{4}$ & Perceived safety has significant influence on attitude towards online buying. & Pearson correlation and regression \\
$\mathrm{H}_{5}$ & Website construction is not a significant factor of attitude towards on online buying. & Pearson correlation and regression \\
$\mathrm{H}_{6}$ & Price of the products does not influence the attitude towards online buying. & Pearson correlation and regression \\
$\mathrm{H}_{7}$ & There is no significant association between quality of products and online buying behavior. & Pearson correlation and regression \\
\hline
\end{tabular}




\section{Research Methodology}

Descriptive research design has been applied in this study. The analyses are totally based on primary data. A structured questionnaire has been used for collecting primary data. The students from a number of selected universities in Chittagong are being selected randomly for the study purpose. The selected universities are East Delta University (EDU), Chittagong Independent University (CIU), Premier University (PU) and International Islamic University Chittagong (IIUC). Non-probability procedure has been applied for selection procedure. Questionnaire was distributed to total 340 students selected randomly from targeted universities and finally 300 students returned the questionnaire after filling up the questionnaire. Respondents were $55.1 \%$ male and $44.9 \%$ female. The respondents were $59.33 \%$ from marketing major as the research was mainly focused on marketing based students and remainder from different other major (see Table-2). This study was done from November, 2017 to January, 2018.

Table 2. Descriptive statistics

\begin{tabular}{|c|c|c|c|}
\hline \multirow{2}{*}{ Variable } & & \multicolumn{2}{|c|}{ Total Respondents (300) } \\
\hline & & Frequency & Percentage \\
\hline \multirow{2}{*}{ Gender: } & Female & 135 & $44.9 \%$ \\
\hline & Male & 165 & $55.1 \%$ \\
\hline \multirow{2}{*}{ Education: } & Under-grade & 195 & $65.0 \%$ \\
\hline & Master & 105 & $35.0 \%$ \\
\hline \multirow{2}{*}{ Major: } & Marketing & 178 & $59.33 \%$ \\
\hline & Others & 122 & $40.67 \%$ \\
\hline \multirow{5}{*}{ Grade: } & Greater than or equal to 3.75 & 50 & $16.67 \%$ \\
\hline & Less than 3.75 but greater than or equal 3.50 & 55 & $18.33 \%$ \\
\hline & Less than 3.5 and greater than or equal to 3.25 & 85 & $28.33 \%$ \\
\hline & Less than 3.25 but greater than or equal to 3.00 & 60 & $20.00 \%$ \\
\hline & Less than 3 & 50 & $16.67 \%$ \\
\hline
\end{tabular}

Statistical tool like descriptive statistics and Pearson's correlation coefficient, regression analysis is used for analysis purpose.

The following econometric model has been developed for analyzing the influential determinants of consumers' attitude toward online shopping.

Where,

$$
A_{i}=\beta_{0}+\beta_{1} G_{i}+\beta_{2} M_{i}+\beta_{3} P_{i}+\beta_{4} W C_{i}+\beta_{5} P_{i}+\beta_{6} Q_{i}+\beta_{7} G R_{i}+\varepsilon_{i}
$$

$A_{i}=$ Attitude of University Students towards Online Shopping. A few questions developed from previous studies have been used for measuring the attitude of students toward online shopping. The researchers have used five point Liket scale for measuring each question's response.

$\mathrm{GE}_{\mathrm{i}}=$ Gender. It is a dummy variable. It takes 1 if gender is male otherwise 0 .

$\mathrm{M}_{\mathrm{i}}=$ Major of the Study in Undergraduate and Graduate Level. It is a dummy variable. If a particular student takes marketing as a major, it takes 1 else 0 .

$\mathrm{PS}_{\mathrm{i}}=$ Perceived Safety. It has been measured by a few set questions selected by reviewing previous literatures. It has been measured by a five point Likert scale.

$\mathrm{WC}_{\mathrm{i}}=$ Website Construction. It basically measures the preference to the website. It has been measured by a few set questions drawn from previous literatures.

$\mathrm{PP}_{\mathrm{i}}=$ Price of Products. It measures the level of the price. The high price denotes 1 and low price denotes 0.

$\mathrm{QP}_{\mathrm{i}}=$ Quality of Products. It measures the preference to the quality of the products.

$\mathrm{GR}_{\mathrm{i}}=$ Grade of the Students. The grades have been segregated in five separate dimensions. It equals 1 if the grade is less than $3.00,2$ if the grade is less than 3.25 but greater than or equal to $3.00,3$ if the grade is less than 3.5 and greater than or equal to $3.25,4$ if the grade is less than 3.75 but greater than or equal 3.50 , Reliability of Data5 if grade is greater than or equal to 3.75 .

Cronbach's alpha measures how closely related a set of items as a group. It is used as a measure of reliability in 
scaling. A high value of alpha does not indicate unidimensional in measurement. Apart from measuring internal consistency, to provide evidence that the scale in question is unidimensional, additional analyses can be done. Strictly speaking, Cronbach's alpha is not a statistical test - it is a coefficient of reliability (or consistency).

$$
\begin{gathered}
\alpha=\frac{N \bar{c}}{\bar{v}+(N-1) \bar{c}} \\
\mathrm{~N}=\text { Number of items }
\end{gathered}
$$

$\overline{\mathrm{c}}=$ The average inter item covariance among the items.

$\overline{\mathrm{v}}=$ The average variance

The alpha coefficient for the four items is 0.921 , implying that the items have relatively high internal reliability. It is mentionable that a reliability coefficient of 0.70 or higher is considered acceptable in most of the research situations.

\section{Correlation Analysis}

Correlation analysis helps to uncover the nature of the relationship among the variables. Pearson's correlation has been used for measuring the level of association. The existence of multicollinearity among the independent variables can also be addressed from the correlation analysis. For example, if the correlation coefficient between two independent variables is either greater than +0.90 or less than -0.90 , then it can be concluded that there exists severe multicollinearity problem. Table-3 presents the Pearson's correlation coefficients among the variables used under study.

From the above correlation matrix, it is seen that male students are significantly associated with the online shopping. Moreover, website construction, quality of the products, and price of the products are significantly positively correlated with the attitude towards online shopping behavior. Since there exists significant positive correlation between quality of the products and gender, male students are really concerned with the quality of the products and the same evidence has been found for the price of the products.

\begin{tabular}{|c|c|c|c|c|c|c|c|c|}
\hline & $A_{i}$ & $\mathrm{GE}_{\mathrm{i}}$ & $\mathrm{M}_{\mathrm{i}}$ & $\mathrm{PS}_{\mathrm{i}}$ & $\mathrm{WC}_{\mathrm{i}}$ & $\mathrm{PP}_{\mathrm{i}}$ & $\mathrm{QP}_{\mathrm{i}}$ & $\mathrm{GR}_{\mathrm{i}}$ \\
\hline$A_{i}$ & 1 & $0.33^{* *}(0.04)$ & $0.12(0.14)$ & $0.22(0.18)$ & $0.13^{* *}(0.01)$ & $0.19^{* * *}(0.00)$ & $0.11^{* * *}(0.00)$ & $0.05(0.77)$ \\
\hline $\mathrm{GE}_{\mathrm{i}}$ & & 1 & $0.34(0.89)$ & $0.28(0.44)$ & $0.06(0.55)$ & $0.39^{* * *}(0.00)$ & $0.56^{* * *}(0.00)$ & $0.11(0.22)$ \\
\hline $\mathrm{M}_{\mathrm{i}}$ & & & 1 & $0.02(0.48)$ & $0.51^{*}(0.09)$ & $0.23(0.13)$ & $0.36(0.67)$ & $0.45(0.72)$ \\
\hline $\mathrm{PS}_{\mathrm{i}}$ & & & & 1 & $0.37(0.79)$ & $0.44(0.93)$ & $0.24(0.89)$ & $0.39(0.88)$ \\
\hline $\mathrm{WC}_{\mathrm{i}}$ & & & & & 1 & $0.33^{* * *}(0.00)$ & $0.49^{* * *}(0.00)$ & $0.43(0.89)$ \\
\hline $\mathrm{PP}_{\mathrm{i}}$ & & & & & & 1 & $0.37^{* * *}(0.00)$ & $0.21(0.79)$ \\
\hline $\mathrm{QP}_{\mathrm{i}}$ & & & & & & & 1 & $0.33(0.98)$ \\
\hline $\mathrm{GR}_{\mathrm{i}}$ & & & & & & & & 1 \\
\hline
\end{tabular}

Table 3. Pearson's correlation coefficient matrix

The quality of the products is highly associated with the price of the products. It is evident from many empirical literatures that the higher the quality, the higher the price. Marketers are inclined to publish the quality products in the website. Hence, quality of the products is significantly associated with the website construction. There is no severe multicollinearity problem among the independent variables.

\subsection{Regression Analysis}

Regression analysis attempts to find out the impact of factors- gender, grade, major, perceived safety, website construction, price of products, and quality of products on attitude towards online shipping. The ordinary least square has been used to estimate equation (1). The following Table- 4 presents the empirical results from the regression. 
Table 4. Estimation results for equation (1)

\begin{tabular}{lll}
\hline Variables & Coefficients \\
\hline $\mathrm{GE}_{\mathrm{i}}$ & $0.11(0.95)$ \\
$\mathrm{GR}_{\mathrm{i}}$ & $0.14(0.37)$ \\
$\mathrm{M}_{\mathrm{i}}$ & $0.18^{* *}(0.03)$ \\
$\mathrm{PS}_{\mathrm{i}}$ & $0.16^{* *}(0.01)$ \\
$\mathrm{WC}_{\mathrm{i}}$ & $0.35^{* * *}(0.00)$ \\
$\mathrm{PP}_{\mathrm{i}}$ & $0.09^{* *}(0.04)$ \\
$\mathrm{QP}_{\mathrm{i}}$ & $0.05^{* *}(0.01)$ \\
\hline
\end{tabular}

Note: ${ }^{* * *, * *, *}$ indicate significant at $1 \%, 5 \%$ and $10 \%$ level respectively. p-values are in parentheses.

From Table-3, it can be said that gender has no significant impact on attitude towards online buying behavior which implies that gender is not matter in the attitude towards online buying. The table also reports that grade of the students is also not considered as an important determinant of attitude towards online buying. It is also evident from the results that that the perceived quality, website construction, price of the products, and quality of the products affect the attitude towards online purchasing behavior of the customer. In addition, major of the students under study was found as an influential factor of the attitude toward online purchasing. The following Table 5 reports about the summary of the results of the hypotheses.

Table 5. Summary of the results of hypotheses testing

\begin{tabular}{cllll}
\hline Hypothesis & Analysis method & Significance & Co-efficient & Results \\
\hline $\mathrm{H}_{1}$ & Regression Analysis & 0.95 & 0.11 & Failed to reject \\
$\mathrm{H}_{2}$ & Regression Analysis & 0.37 & 0.14 & Failed to reject \\
$\mathrm{H}_{3}$ & Regression Analysis & 0.03 & $0.18^{* *}$ & $0.16^{* *}$ \\
$\mathrm{H}_{4}$ & Regression analysis & 0.01 & $0.35^{* * *}$ & Rejected \\
$\mathrm{H}_{5}$ & Regression analysis & 0.00 & $0.09^{* *}$ & Rejected \\
$\mathrm{H}_{6}$ & Regression analysis & 0.04 & $0.05^{*}$ & Rejected \\
$\mathrm{H}_{7}$ & Regression analysis & 0.01 & Rejected \\
\hline
\end{tabular}

Note: ${ }^{* * *},{ }^{* *},{ }^{*}$ indicate significant at $1 \%, 5 \%$ and $10 \%$ level respectively.

It can be concluded from the Table-5 that out of 7 hypotheses, 5 hypotheses are rejected, means that out of 7 variables 5 variables have significant impact on attitude towards online buying.

\section{Conclusion and Recommendation}

In Bangladesh most of the online business have been started following social media like Facebook. Majority of the students of tertiary level are using Facebook. A bulk amount of time per day is being spent by the students in online. Therefore, it is inevitable for the sellers via internet as well as Facebook to know the factors influencing the attitude of University students' towards online buying so that they can give emphasis on core factors. A few crucial suggestions can also be disseminated to the associated companies who are interested to sell their products via online.

The main objective of the study is to examine the factors influencing the attitude of University students toward online buying through internet as well as Facebook. The primary data analysis concludes that the attitude towards online buying differ according to their major which suggests that students with different major have focus on different websites. Sellers need be become more specialized in constructing websites while offering the specialized services and products to the students specifically students at University level.

In addition, the results also show that a significant positive association exists between University students' attitude towards online buying and perceived safety. Sellers should focus on the safety during the transaction through online. During buying in online, a particular buyer usually provides the details information. As a result, there is a risk of diffusion of private information in internet. Hence, a portion of the students under study is found to become worried about the privacy of their information. Moreover, there is a chance of hacking pin and 
passwords of debit card during the online transaction. Sellers should advance their online security by improving the technology and other security alliances. Sellers should give assurance to the consumers about the safety of information of consumer.

In the same way, the results also reveal that the price of the product has a significant impact on the attitude of students online buying. Most of the students are getting limited amount of money from their parents for regular expenses, so the students negatively react to the increase in price of the online products. The seller can charge a sensible price from the students specifically they can offer some discount to the University students.

The results also show that there is a significant association between the attitude of University students towards online buying and consumers' perception of products. In this regard, sellers can prove that the products offering to sell via online received quality certificates after examining the required tests. The consumer will be more inclined to buy the products from online if he becomes to know that the products in online are good and have passed all the necessary tests. Sellers can also give an option to the consumers about the refund of the money if the consumer do not satisfy with the products, as a result the trust of the customers would increase.

Finally, construction of website is also found as a significant determinant of the attitude of University students towards online buying. Evidence also implies that the University students are more sensitive about the design and structure of the website. The sellers should redesign the website in such a way so that it will attract the University students.

\section{References}

Ajzen, I. (1991). The theory of planned behavior. Organizational Behavior and Human Decision Processes, 50, 179-211. https://doi.org/10.1016/0749-5978(91)90020-T.

Alkasassbeh, W. A. K. (2014). Factors Affecting Consumers' Attitudes toward Online Shopping in the City of Tabuk. European Journal of Business and Management, 6(18), 213-222.

AL-Ziadat, M. T., AL-Majali, M. M., Al-Muala, A. M., \& Khawaldeh, K. H. (2013). Factors Affecting University Student's Attitudes toward E-Commerce: Case of Mu'tah University. International Journal of Marketing Studies, 5(5), 88-93. http://doi:10.5539/ijms.v5n5p88

Bellman, S., Lohse, G. L., \& Johnson, E. J. (1999). Predictors of Online Buying Behavior. Communications of the ACM, 4(12), 32-38. https://doi.org/10.1145/322796.322805

Dani, N. J. (2017). A Study on Consumers' Attitude Towards Online Shopping, International Journal of Research in Management \& Business Studies, 4(3), 42-46. https://doi.org/10.1108/IntR-05-2014-0146

Daud, N. M., Mohd, N. R. N., Shamsudin, N. S., Zaidan, N. K., \& Mohamed, I. S. (2016). Factors that influence student's behavior on online shopping in Malaysia. PONTE International Scientific Research Journal, 72(4), 117-126. https://doi.org/10.21506/j.ponte.2016.4.10

Delafrooz, N., Paim, L., Haron, S. M., Sidin, S., \& Khatibi, A. (2009). Factors affecting students' attitude toward online shopping. African journal of Business Management, 3, 200-209.

Donthu, N., \& Garcia, A. (1999). The Internet Shopper. Journal of Advertising Research, 39(3), 52-58.

Garbarino, E., \& Strahilevitz, M. (2004). Gender differences in the perceived risk of buying online and the effects of receiving a site recommendation. Journal of Business Research, 57, 768-775. https://doi.org/10.1016/S0148-2963(02)00363-6

Halimi, A. B., Chavosh, A., Choshalyc, S. H., Esferjani, P. S., \& Doghezlou, A. (2012). Factors Affecting Consumers' Attitude Towards Online Purchasing Among Degree Holders in Singapore. International Conference on Economics, Business and Marketing Management (EBMM 2011), Shanghai, China, 118-122. Retrieved from https://ssrn.com/abstract=2009242

Jadhav, V., \& Khanna, M. (2016). Factors Influencing Online Buying Behavior of College Students: A Qualitative Analysis. The Qualitative Report, 2l(1), 1-15.

Jukariya, T., \& Singhvi, R. (2018) A Study of Factors Affecting Online Buying Behavior of Students. International Journal of Current Microbiology and Applied Sciences, 7(1), 2558-2565. https://doi.org/10.20546/ijcmas.2018.701.308

Jun, G., and Jaafar, N. I. (2011). A Study on Consumers' Attitude towards Online Shopping in China. International Journal of Business and Social Science, 2(11), 122-132.

Karayanni, D. A. (2003). Web-shoppers and non-shoppers: Compatibility, relative advantage and demographics. 
European Business Review, 15(3), 141-152. https://doi.org/10.1108/09555340310474640

Korgaonkar, P. K., \& Wolin, L. D. (1999). A multivariate analysis of web usage. Journal of Advertising Research, $39(2), 53-68$.

Koufaris, M. (2002). Applying the technology acceptance model and flow theory to online consumer behavior. Information Systems Research, 13(2), 205-223.

Li, H., Kuo, C., \& Russell, M. G. (1999). The impact of perceived channel utilities, shopping orientations, and demographics on the consumer's online buying behavior. Journal of Computer-Mediated Communication, 5(2), 1-20. https://doi.org/10.1111/j.1083-6101.1999.tb00336.x

Ma, M., \& Ma, R. (2012). The Factors Affecting the Attitude of University Students towards Online Shopping. In Jin D., Lin S. (Eds.), Advances in Electronic Commerce, Web Application and Communication. Advances in Intelligent and Soft Computing (Vol. 149, pp. 511-515). https://doi.org/10.1007/978-3-642-28658-2_79

Mahmud, Q. M., \& Hossain, S. (2014). Factors Influencing Customers' Attitude Towards Online Shopping: Evidence from Dhaka City. Journal of Business Studies, 35(3), 161-174.

Makhitha, K. M. (2014). Factors Influencing Generations Y students' Attitude towards Online Shopping, Mediterranean Journal of Social Sciences, 5(21), 39-50. https://doi.org/10.5901/mjss.2014.v5n21p39

Pavlou, P. A. (2003). Consumer acceptance of electronic commerce: Integrating trust and risk with the technology acceptance model. International Journal of Electronic Commerce, 7(3), 69-103.

Pavlou, P. A., \& Fygenson, M. (2006). Understanding and predicting electronic commerce adoption: An extension of the theory of planned Behavior. MIS Quarterly, 30(1), 115-143. https://doi.org/10.2307/25148720

Rajesh, R. (2018) Evaluating the Factors Influencing Online Shopping and Its Consumer Satisfaction in Pune Area. PEOPLE: International Journal of Social Sciences, 4(1), 54-76.

Sharma, S., \& Sitlani, M. (2013). Online Shopping among Higher Education Students in Indore: A Factor Analysis Approach, Indian Journal of Marketing, 43(1).

Swinyard, W. R., \& Smith, S. M. (2003). Why People Don't Shop Online: A Lifestyle Study of the Internet Consumers. Psychology and Marketing, 20(7), 567-597. https://doi.org/10.1002/mar.10087

Sylke, V. C., Belanger, F., \& Comunale, C. L. (2002). Gender differences in perceptions of Web-based shopping. Communications of the ACM, 45(8), 82-86. https://doi.org/10.1145/545151.545155

Weiss, M. J. (2001). Online America. American Demographics, 23(3), 53-56.

\section{Copyrights}

Copyright for this article is retained by the author(s), with first publication rights granted to the journal.

This is an open-access article distributed under the terms and conditions of the Creative Commons Attribution license (http://creativecommons.org/licenses/by/4.0/). 